DOI:10.31933/DIJMS

Received: $18^{\text {th }}$ August 2020, Revised: $15^{\text {th }}$ September 2020, Publish: 5 November 2020

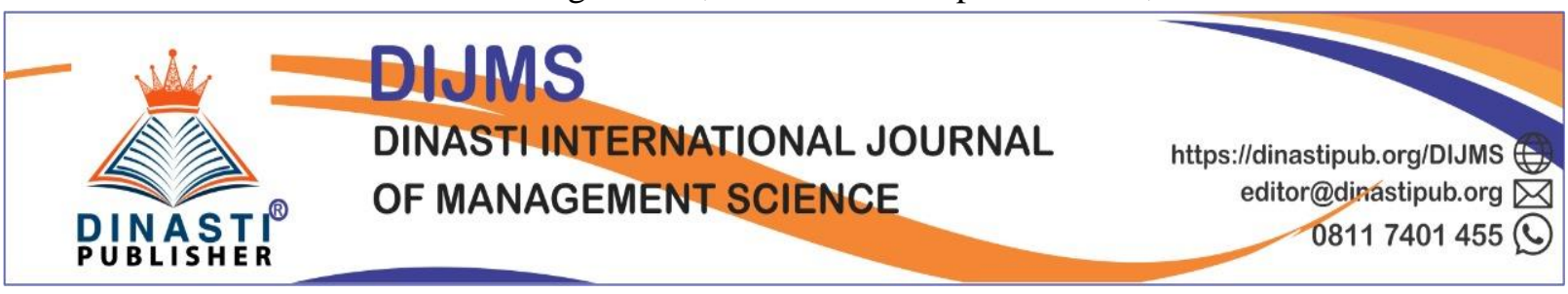

\title{
THE IMPACT OF COVID 19 ON THE UMRAH AND HAJJ BUSINESS PLUS IN EAST JAKARTA
}

\author{
Ryan Firdiansyah" ${ }^{1)}$, Basneldi' ${ }^{2}$, IG.N.Willy Hermawan ${ }^{3)}$, Muzayyanah Yuliasih" ${ }^{4}$, Bekti \\ Setiadi ${ }^{5}$ ) \\ ${ }^{1)}$ Sekolah Tinggi Penerbangan AVIASI, ryan@stp-aviasi.ac.id \\ 2) Jakarta Global University (JGU), Jakarta, Indonesia, basneldi69@ gmail.com \\ ${ }^{3)}$ Sekolah Tinggi Penerbangan AVIASI, willy.hermawan75@gmail.com \\ ${ }^{4)}$ Sekolah Tinggi Penerbangan AVIASI, 99muzayyanah@gmail.com \\ ${ }^{5}$ Sekolah Tinggi Penerbangan AVIASI, bekti_setiadi@yahoo.com
}

\section{Correspondence Author: Muzayyanah Yuliasih}

\begin{abstract}
The purpose of this study is to find out the state of the Umrah and Hajj travel agents in the face of the Covid 19 pandemic that is currently happening. The research method used in this study is a descriptive study with a qualitative analysis approach, and uses the results of informant interviews and secondary data from correspondence reports that help provide secondary data to support this research. Corona virus or corona virus disease 2019 (Covid-19) has made the domestic economy contract, the Ministry of Finance noted several problems caused by the outbreak of this virus increased unemployment rate 1.2 million formal sector and 265,000 informal sector, Indonesian Purchasing Managers Index (PMI) below level 50 which is only 45.3 in March 2020. Third, more than 12,703 flights at 15 airports were canceled from January to February, with details of 11,680 domestic flights and 1,023 international flights, the government of Saudi Arabia also issued rules prohibiting the use of Umrah for all countries. This problem will affect the organizers of Umrah or Umrah travel in Indonesia, researchers take samples, especially in the area of East Jakarta, research using descriptive methods with a qualitative analysis approach, this research uses the method by interviewing directly from competent sources in the field of aviation, organizing umrah.
\end{abstract}

Keywords: Covid 19, umrah, hajj plus

\section{INTRODUCTION}

The Corona 19 virus (Covid 19) which struck and made the current epidemic in the world made all aspects of life and business suffer. Corona 19 virus (Covid 19) originating from the People's Republic of China (PRC) precisely from Wuhan, Hubei Province, in December 2019. (Adityo Susilo, C. Martin Rumende, Ceva W Pitoyo, Widayat Djoko Santoso, Herikurniawan, Robert Sinto , Gurmeet Singh, Leonard Nainggolan, Mira Yulianti, Erni J Nelwan, Lie Khie Chen, Alvina Widhani, Edwin Wijaya, Bramantya Wicaksana, Maradewi Maksum, Firda Annisa, ChyntiaOM Jasirwan, Evy Yunihastuti, 2020). This corona 19 virus directly to the pilgrimage business and pilgrimage is by not permitting travel pilgrims who have pilgrims and the date of departure was canceled, due to an appeal from Saudi Arabia to prohibit the entry of pilgrims from various countries. 
Umrah and not an obligation for Muslims, but there are several types of Umrah pilgrims who become Umrah passengers who will go to the holy land, among others moderate (want to be served, have knowledge and the cost does not make a problem) and mediun (this type of passenger is the obstacle of passengers Umrah pilgrims where they for Umrah are willing to save and sell something in their area so that they can Umrah and do not have knowledge related to aviation). Umrah is the same as a trip which is different from the Hajj which only takes place on a certain date in the month of Hajj (khusnul, khotimah, 2014). Indonesian people, especially Muslims, are very many who go to run the pilgrimage from year to year, this religious tourism is very preferred by Muslims and in the implementation of this pilgrimage community uses existing travel agencies with various kinds or variations in prices in each region and province in Indonesia.

Specifically in the Jakarta Special Capital Region province in the East Jakarta area, there are about 135 travel agencies that have licenses and are operating to date and can dispatch people or Umrah pilgrims who wish to worship to the country of Saudi Arabia. Umrah and not an obligation for Muslims, but there are several types of Umrah pilgrims who become Umrah passengers who will go to the holy land, among others moderate (want to be served, have knowledge and the cost does not make a problem) and mediun (this type of passenger is the obstacle of passengers Umrah pilgrims where they for Umrah are willing to save and sell something in their area so that they can Umrah and do not have knowledge related to aviation) (Bambang Soekarsono, Ryan Firdiansyah, IG.P. Willy Hermawan, 2018).

Thousands of Umrah pilgrims have been dispatched from year to year by the Umrah travel agency in East Jakarta, but in 2020 precisely in February 2020 Indonesia was shocked by the news that Umrah pilgrims should not be sent to Saudi Arabia due to the corona virus pandemic that struck the country with the positive citizens affected by this corona virus. The Saudi Arabian government began to close the Grand Mosque in the City of Mecca and the Prophet's Mosque in Medina on February 27, 2020 due to the corona outbreak. Regional quarantine applies. All pilgrims from various countries were repatriated. New arrivals are also welcome back again. Moreover those who delayed their departure to the Holy Land to perform the pilgrimage. It is not yet known when the Government of Saudi Arabia will reopen access for worshipers to worship there. Now, the Haram Mosque and Nabawi Mosque areas have been opened although they only accept a limited number of worshipers. (Https://travel.tempo.co/read/1345759/batal-umroh-karena-wabah-corona-ikut-tur-virtual-umrohh -used / full $\&$ view $=$ ok).

This news made the pilgrims who had already ordered and the travel bureau there was surprised and made them roll their minds because of the prohibition to enter Saudi Arabia because of the corona virus pandemic that hit the country of Saudi Arabia. Travel agencies in the initial prohibition to enter Saudi Arabia have burdens because they have booked flight tickets, hotels and other accommodations for pilgrims who have paid in full to the travel agency. The travel bureau directly has made an agreement with the passenger to refund pilgrimage or not, all of that is the policy of the travel bureau. In running the Umrah and Hajj travel business, it is very beneficial for the travel bureau, from every Umrah pilgrims who will go on the pilgrimage, the travel bureau will get USD 300 (Umrah business / Hajj \& Umrah travel business profits are tempting-Corporation OkezoneNews.html). The data obtained for each pilgrims who can benefit from Umrah pilgrims and Apabilla travel agents who can send pilgrims to Saudi Arabia twice a year and once departing there are 300 pilgrims for travel agents in East Jakarta will benefit. which is huge for a travel agency in running a business for Umrah and Hajj during normal times.

According to data from the Business Development Coordinator of the Indonesian Travel Association (Asita) Jakarta Pauline Suharno said, living in the business world of Hajj and Umrah travel is indeed fun. Not only the benefits, this business also helps Muslims to reach their goals of touching the Kaaba. The umroh business, even though the profit margin is small is only 3-5\%, but this business is always busy with enthusiasts and can be done every month. "The profit margin is 3-5\% at most, the rest is from the service fee. Every month many depart. Certainly the market segment is clear (source from SoloPos.com in March 2014). In the current pandemic, the Umrah and Hajj Plus businesses are among the business sectors that have been impacted. After February 2020 the Saudi Arabian country banned Umrah pilgrims from entering Saudi Arabia due to an outbreak, so this was a concern for the Umrah travel bureau during this epidemic.

From the description of the margin above, in the absence of an outbreak, it can get maximum benefits, then at a time like the corona virus pandemic as it is today, the travel agency will rethink the sustainability and sustainability of the Umrah and Hajj Plus businesses. The results of research from 
Dewi Masitah (Islamic High School (STAI) Al-Yasini Sidoarjo) revealed business results in the name of religion over religion were commodities, the results of detailed discussion.

\section{RESEARCH METHODS}

This research is a descriptive study with a qualitative analysis approach, and uses the results of information interviews as research data. The selection of research designs is based on several considerations, including: semi-qualitative writing is used to describe the background of complex interactions, field evidence that will provide a proper understanding.

This research was also assisted by correspondence in retrieving the data needed.

\section{FINDINGS AND DISCUSSION}

After carrying out a qualitative data retrieval to the travel agency conducted for two months carried out by this group of researchers, the results obtained will be discussed in this study. The results of the data obtained from the four travel agencies that we chose and assisted by a correspondence from one of the researchers obtained data in the current atmosphere of the 19th pandemic, the Umrah and Hajj travel agencies were devastated and had to rack their brains in maintaining the consistency of their business continuity. Secondary data obtained from the travel agency Umrah and Hajj plus such as from Safir Amal Imani, Madani Tour, Al Hijaz Tour and Travel, Bahjah Tour and Travel. The data obtained will be described and analyzed ;

Table 1. Umrah Pilgrimage Candidates. Umrah and Umrah Travel Bureau Safir Amal Imani

\begin{tabular}{|c|c|c|c|}
\hline Nama Travel & Embarkation & Total Group & Total Pilgrims (Passengers) \\
\hline Safir Amal Imani & $\begin{array}{c}8 \text { January } 2020 \\
19 \text { February } 2020 \\
19 \text { March } 2020\end{array}$ & $\begin{array}{l}2 \text { Group } \\
2 \text { Group } \\
2 \text { Group }\end{array}$ & $\begin{array}{c}\text { 83 Jamaah } \\
\text { 80 Jamaah } \\
\text { 61 Jamaah (failed to } \\
\text { Embarkation until now) }\end{array}$ \\
\hline Madani Tour & $\begin{array}{c}27 \text { January } 2020 \\
26 \text { February } 2020 \\
19 \text { March } 2020\end{array}$ & $\begin{array}{l}2 \text { Group } \\
1 \text { Group } \\
2 \text { Group }\end{array}$ & $\begin{array}{c}\text { 45 Jamaah } \\
\text { 64 Jamaah } \\
\text { 76 Jamaah (failed to } \\
\text { Embarkation until now) }\end{array}$ \\
\hline $\begin{array}{c}\text { Al Hijaz Tour } \\
\text { Travel }\end{array}$ & $\begin{array}{c}26 \text { February } 2020 \\
19 \text { March } 2020\end{array}$ & $\begin{array}{l}2 \text { Group } \\
2 \text { Group }\end{array}$ & $\begin{array}{c}\text { 90 Jamaah } \\
\text { 90 Jamaah (failed to } \\
\text { Embarkation until now) }\end{array}$ \\
\hline $\begin{array}{c}\text { Bahjah Tour } \\
\text { Travel }\end{array}$ & $\begin{array}{c}26 \text { February } 2020 \\
19 \text { March } 2020\end{array}$ & $\begin{array}{l}1 \text { Group } \\
1 \text { Group }\end{array}$ & $\begin{array}{c}30 \\
25 \text { (failed to Embarkation } \\
\text { until now) }\end{array}$ \\
\hline
\end{tabular}

From the description of the data above that in March 2020 for the departure of Umrah pilgrims from all travel tour bureaus could not be departed by a warning from Saudi Arabia to not send Umrah pilgrims from all over the world including Indonesia. Responding to this from the results of an interview with the owner of the travel bureau chose to budge and accept the decision of the government of Saudi Arabia not to dispatch pilgrims. Our analysis is to continue to be able to run this business, then the Umrah travel tour bureau is the government providing assistance or guarantees for Umrah businesses or businesses as above by thinking about whether there are incentives to the Umrah travel tour bureau, such as the data held by government below ; 


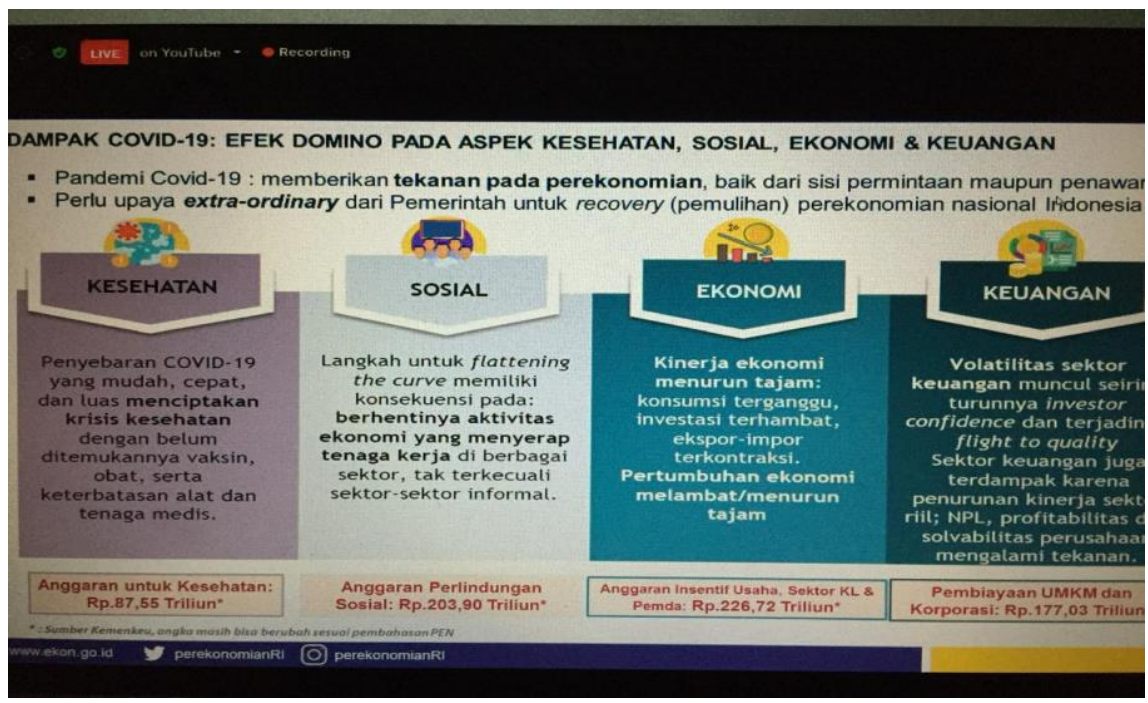

Figure 2. Exposure from the Ministry of Finance of the Republic of Indonesia

From the picture it can be seen that the impact of Covid - 19; cause a domino effect on health, social, economic and financial aspects, put pressure on both the demand and supply sides, and need extraordinary efforts from the government for the recovery of the national economy. In connection with the travel tour bureau from the table above, the government prepares an incentive budget for two economic and financial posts, for the Umrah travel tour bureau may be included in one of the categories that can receive incentives from the government. In our view, this incentive is provided by the government on condition that the For this reason, the government or through the regional government needs to socialize the Umrah and Hajj tour travel businesses plus those affected by this pandemic.

The above description is with incentives for businesses in all fields, especially Umrah and Hajj tour travel agencies that are directly affected by the cancellation of departures so that prospective pilgrims cannot leave for the holy land in carrying out the pilgrimage. Our other analysis is that the Umrah and Hajj tour tour operators plus still have to foster pilgrims who do not go by giving them the opportunity to depart when this pandemic period ends, and return the money of prospective non-departing pilgrims who have entered Umroh travel tour bureau and Hajj plus. This is very heavy from the results of direct interviews of travel tour bureau owners to run company operations relying solely on pilgrims who will perform Umrah or Hajj plus on Hajj, both burdens to pay salaries to employees who work are very burdensome and make companies look for ways to deal with covid pandemic 19 period at this time, employees as one of the elements that run operations inevitably home first because there are no activities from prospective pilgrims who register or pilgrims who will berangkan to the holy land to perform the pilgrimage and pilgrimage. Third, there are companies that continue to run as they are by reducing employee salaries in difficult times like this.

From the data below as a comparison for the growth of the Indonesian economy according to the most recent data from the Ministry of Finance; 


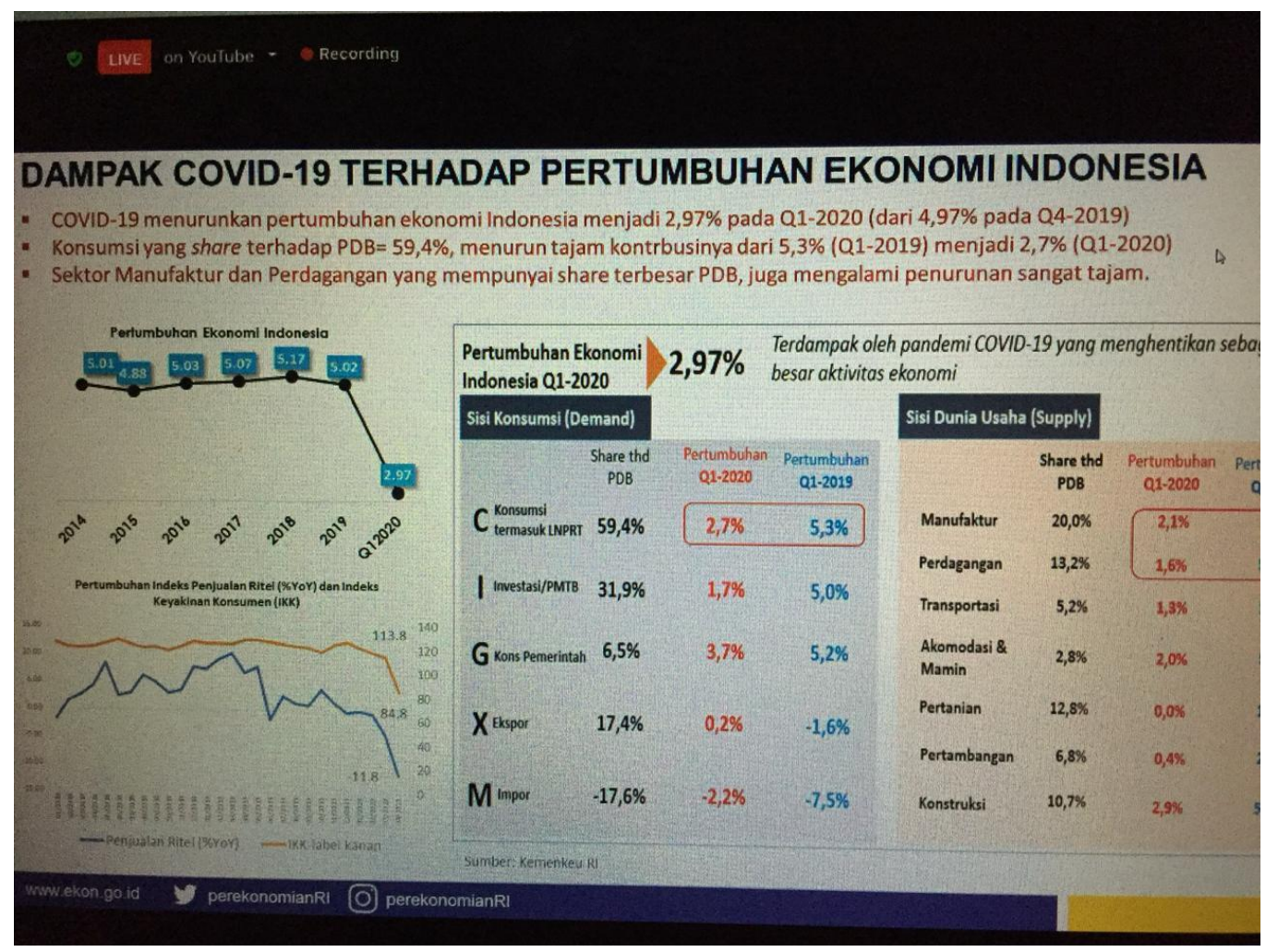

Figure 3. Exposure from the Ministry of Finance

There is a connection or not with the business tour travel Umrah and Hajj Plus which has been described data, will be explained a little about Indonesia's economic growth when the Covid Pandemic 19, from the results of the data above that the existence of Covid 19 reduced Indonesia's economic growth to $2.97 \%$ in Q1- 2020 (from 4.97\% in Q4-2019), when related to data starting in March 2020 where there was an appeal not to send pilgrims to Umrah with the covid 19 pandemic, then this travel tour bureau could not do anything because of appeals it is comprehensive for all countries in the world. As a contributor to economic growth from the Umrah travel tour business, the impact is there and felt. Data from the data above the two consumption shares of GDP $=59.4 \%$ decreased sharply from $5.3 \%$ (Q1-2019) to 2.7\% (Q1-2020). From the travel tour business Umrah and Hajj is not too prominent for GDP, it's just that from the data above the manufacturing and trade sectors have the largest in GDP, experiencing a sharp decline.

\section{CONCLUSION AND SUGGESTIONS}

From the results of this study it can be concluded that the impact of the covid 19 virus which is very influential on the world economy, including Indonesia, including its impact on the implementation of the pilgrimage, plus a ban from the government of Saudi Arabia starting in February as evidenced by the results of this study several Umrah organizing bureaus in East Jakarta canceling the departure of the congregation, while fixed costs must be issued, for pilgrims who failed to leave while the ticket, round trip accommodation costs, airplane transportation, visa has been issued by the travel bureau, this problem will burden him, if later Saudi Arabia reopens Umroh faucet, the effect is that some Umrah bureaus temporarily close their companies.

If from the Ministry of Finance's exposure data above there is an incentive for business owners including the Umrah travel tour bureau who will also get these incentives then it will be very helpful in sustainability or can help the operating Umrah travel tour bureau can continue to run under conditions and conditions of the Covid 19 pandemic such as currently. The incentive for the Umrah travel tour bureau is very necessary in my opinion but the owner of the travel tour bureau has not received information about who is entitled to the incentive. 


\section{REFERENCE}

Adityo Susilo, C. Martin Rumende, Ceva W Pitoyo, Widayat Djoko Santoso, Herikurniawan, Robert Sinto, Gurmeet Singh, Leonard Nainggolan, Mira Yulianti, Erni J Nelwan, Lie KhieChen, Alvina Widhani, Edwin Wijaya, Bramantya Wicaksana, Maradewi Maksum, Firda Annisa, 2020.

ChyntiaOM Jasirwan, Evy Yunihastuti, Jurnal Penyakit Dalam Indonesia, Vol. 7, No. 1 Maret

Bambang Soekarsono, Ryan Firdiansyah, IG.P. Willy Hermawan, Dinamika Penanganan Penumpang Jamaah Umroh dan Haji plus oleh Perusahaan Wisata, Haji, Umroh (WHU) di Bandar Udara Soekarno-Hatta, Jurnal Ilmiah Kedirgantaraan, Vol. 2, pages 1-14, Desember 2018.

Data Asosiasi Perjalanan Wisata Indonesia (Asita)

Dewi Masitah, Dinamika Bisnis Travel Umroh Se Kota Pasuruan diEraGlobalisasi, Iqtishadia, Vol. 2, No. 2, Desember 2015.

https://travel.tempo.co/read/1345759/batal-umroh-karena-wabah-corona-ikut-tur-virtual-umrohdulu/full\&view=ok).

https://bisnis umroh/Keuntungan bisnis travel haji \& umroh menggiurkan-Korporasi OkezoneNews.html

Paparan Kementrian Keuangan RI

SoloPos.com Maret tahun 2014.

Data Sekunder dari Biro Tour Travel umroh di Jakarta Timur dengan bantuan korespodensi dan wawancara. 